\title{
How challenges made us stronger
}

\section{Giustino Varrassi ${ }^{1, *}$}

\author{
${ }^{1}$ Paolo Procacci Foundation, Via Tacito 7, 00193 Rome, Italy
}

\section{*Correspondence}

giuvarr@gmail.com (Giustino Varrassi)

One year ago, Signa Vitae management invited me to become Editor-in-Chief of this interesting and intriguing journal. At that moment, the world was still suffering from the terrible pandemic of COVID-19, many professional initiatives were shutting down, and so many colleagues were revising their personal objectives. Most academic publishers were having trouble keeping up with normal activities. Everyone had to make major adaptations in their work and home life. This was a stimulating time - for some of us, the challenges to adapt ourselves to the pandemic were exciting new opportunities, but for others, it was a time of loss and restriction. At Signa Vitae, we welcomed the work, difficult as it was on some days. As it is well known, work is an excellent gym to exercise the intelligence, and hard work even under difficult conditions can still bring big rewards.

What happened with Signa Vitae in the last 12 months is the best evidence of the previous assertion. In a moment of general crisis, we (the Editorial Team) inherited a journal with many problems, few submissions, organizational troubles, and an impact factor that was close to zero (0.338). We accepted this challenge and worked intensively, because we saw opportunities in this critical moment.

In 2021 Signa Vitae has increased all the numbers: submissions, publications, references, and impact factor. In Table 1 there are a few examples.

TA B L E 1. Some of the indicators.

\begin{tabular}{|lll|}
\hline Items & $\mathbf{2 0 2 0}$ & $\mathbf{2 0 2 1}$ \\
\hline Articles & Submitted: 384 & Submitted: 590 \\
& $\begin{array}{l}\text { Accepted: } 120 \\
\text { Published: } 120\end{array}$ & $\begin{array}{l}\text { Accepted: } 180 \\
\text { Published: } 180\end{array}$ \\
\hline Number of issues & 2 & 6 \\
\hline Special Issues & 27 & 41 \\
\hline Authors & 664 & 2158 \\
\hline Citations & $140^{*}$ & $\begin{array}{l}204 \text { (Data at } 10 \text { De- } \\
\text { cember 2021)** }\end{array}$ \\
Impact Factor* & 0.630 & $\begin{array}{l}0.750 \quad(\text { Real time, } \\
\text { Data at } 10 \text { Decem- } \\
\text { ber 2021)** }\end{array}$ \\
\hline
\end{tabular}

*Data from JCR, **Data from WoS.
The 10 most-viewed published articles represent an interesting aspect in the evolution of the journal. There has been a phenomenal increase with over 35,700 views per month, having Nardelli et al. [1] at the peak with 18,986 views. Immediately after that paper, there are all the other nine [2-10]. Most of them are related to COVID-19 and its impact on the health care systems. A further important impact on the scientific community is represented by the 10 most downloaded papers published this year.

One clear indicator of interest is the number of citations, demonstrating the huge increase in the impact of the journal on the scientific community. Not only did we stay in publication, we were growing in influence. Based on these numbers, the impact factor of the journal is going to be over 1 in a short time (108 published papers and 204 citations, this year) (Fig. 1), even if the real-time impact factor on web of science (WoS) is 0.750 (Table 1). It is difficult to overstate the importance of this metric.

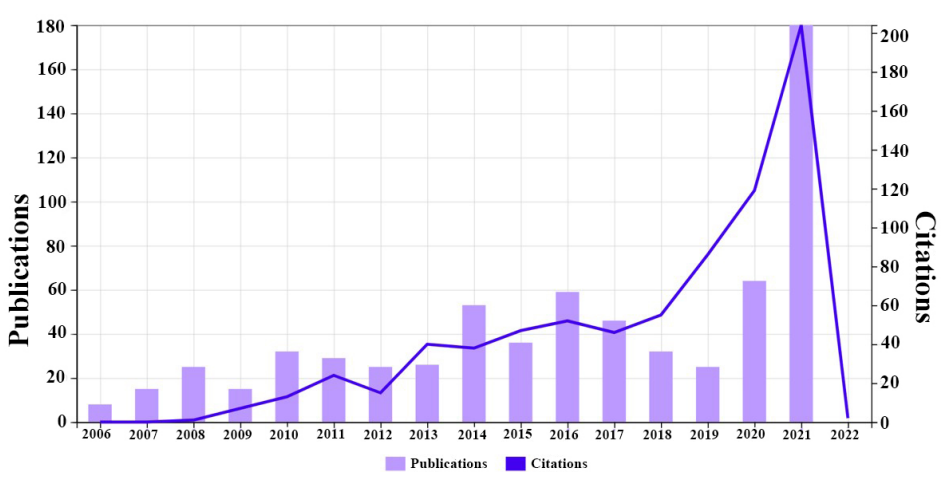

F I G U R E 1. Times cited and publications over time. Data from WoS.

The articles published in 2021 have already been cited several times. The most cited is Nioi et al. [11], which shows the huge interest of the scientific community in COVID-19 and its consequences on the health care.

With the wind in our sails, we are sailing towards a 2022 full of further challenges and successes. For this. we thank our loyal readers, all the expert and generous reviewers that have increased the quality of the submitted manuscripts, the editors strongly supporting the editorial activities, and all the authors 
who, increasingly numerous, continue to trust Signa Vitae.

\section{ETHICS APPROVAL AND CONSENT TO PARTICIPATE}

Not applicable.

\section{ACKNOWLEDGMENT}

The author acknowledges the Paolo Procacci Foundation for the support in the editorial activities.

\section{FUNDING}

This research received no external funding.

\section{CONFLICT OF INTEREST}

The author declares no conflict of interest. He is serving as Editor in Chief of this journal.

\section{REFERENCES}

[1] Nardelli P, Zangrillo A, Sanchini G, Likhvantsev VV, Yavorovski AG, Romero Garcia CS, et al. Crying wolf in time of Corona: the strange case of ivermectin and hydroxychloroquine. Is the fear of failure withholding potential life-saving treatment from clinical use? Signa Vitae. 2021;17: 3-4.

[2] Pergolizzi JV, LeQuang JA, Magnusson P, Myrcik D, Varrassi G. It's not over till it's over: a narrative review of long COVID. Signa Vitae. 2021;17: 21-30.

[3] Lim HK, Wang JM, Hung ST, Ku HC. A dangerous cause of airway obstruction: deep neck infection. Signa Vitae. 2021;17: 4-9.

[4] Camilloni A, Nati G, Maggiolini P, Romanelli A, Carbone G, Giannarelli $\mathrm{D}$, et al. Chronic non-cancer pain in primary care: an Italian crosssectional study. 2021;17: 54-62.

[5] Pergolizzi JV, LeQuang JA, Taylor R, Wollmuth C, Nalamachu M, Varrassi G, et al. Four pandemics: lessons learned, lessons lost. Signa Vitae. 2021;17: 1-5.

[6] Varrassi G, Pergolizzi JV. Ibuprofen safety at the golden anniversary. A commentary and recent developments. Signa Vitae. 2021;17: 1-3.

[7] Erdem AB, Oğuztürk H, Tümer M, Işı1k B, Kayipmaz AE, Korkut S. Reliability of the Pneumonia Severity Score (PSI) Index in patients diagnosed with COVID-19 pneumonia to determine outpatient discharge. Signa Vitae. 2021;17: 48-53.

[8] Mazza F, Venturino M, Turello D, Gorla A, Degiovanni G, Locatelli A, et al. Cricothyroidotomy in the emergency setting: indications, techniques and outcomes. Signa Vitae. 2021;17: 31-41.

[9] Zhou YW, He YQ, Yao R. The impact of first timing of antibiotics for community acquired pneumonia in emergency department. Signa Vitae. 2021;17: 20-27.

[10] Santos MD, Oh KS, Varrassi G, Nagrale D. Multimodal analgesia for postoperative pain in Asia: a review of evidence with clinical focus on dexketoprofen and tramadol/dexketoprofen fixed-dose combination. Signa Vitae. 2021;17: 1-7.

[11] Nioi M, Napoli PE, Finco G, Demontis R, Fossarello M, d'Aloja E. Fear of COVID-19 and medical liability. Insights from a series of 130 consecutives medico-legal claims evaluated in a single institution during SARS-CoV-2-related pandemic. Signa Vitae. 2021;17: 79-85.

How to cite this article: Varrassi G. How challenges made us stronger. Signa Vitae. 2022;18(1):1-2. doi:10.22514/sv.2022.001. 